\title{
Comparative Study of Some Physico-Chemical, Microbiological Parameters and Origins of Faecal Contamination of Three Types of Soybean Flour Sold in the City of Daloa (Côte d'Ivoire)
}

\author{
Kouassi Kra Athanase ${ }^{1,2 *}$, Gnanwa Mankambou Jacques ${ }^{1}$, Kouassi Kouassi Clément ${ }^{1,2}$, \\ Coulibaly Bakary ${ }^{1}$ and Coulibaly Ibourahema ${ }^{1}$
}

${ }^{1}$ Jean Lorougnon GUEDE University, Biochemistry-Microbiology Department, Agrovalorisation Laboratory, BP 150 Daloa, Côte d'Ivoire

${ }^{2}$ NanguiAbrogoua University, Department of Food Science and Technology, Laboratory of

Food Biotechnology and Microbiology, 02 BP 801 Abidjan 02, Côte d'Ivoire

*Corresponding author

Keywords

Flour, plant, agronomic, nutritional and economic

Article Info

\section{Accepted:}

20 June 2021

Available Online:

10 July 2021
The aim of this study is to compare the physicochemical and microbiological parameters of soya flour, but also to determine the origin of faecal contamination of the latter. To carry out the work, three types of flour consisting of 60 soybean samples were used. In addition, the method proposed by AOAC, (1995) made it possible to determine the physicochemical parameters such as dry matter, ash, $\mathrm{pH}$, moisture content and titratable acidity dosage. The microbiological analyzes enabled the enumerations of yeasts and molds, fecal coliforms, aerobic mesophilic germs, Bacillus cereus, detection and enumeration of E. coli, Staphylococcus aureus and faecal streptococci. The determination of the origins of faecal contamination was carried out according to the work of Borrego and Romero (1982). The results show that there is no significant difference between the different types of flour at $\mathrm{P}>0.05$ at the 5\% level for the different physicochemical parameters. However, at the level of microbiological parameters, a significant difference is noted between the F2 flour and the two other types, namely F1 and F3, at the level of Mesophilic Aerobic Germs, E. coli and Staphylococcus aureus. There is also a significant difference between the F3 flour and the two other types of flour namely the F 1 and the F2 at the level of Bacillus cereus. Furthermore, a significant difference is also noted between F1 flour and the two other types of flour, namely F2 and F3 in faecal streptococci. In addition, we see the source of contamination of $\mathrm{F} 1$ is of mixed origin, predominantly human, while $\mathrm{F} 2$ and F3 flour, the source of contamination is strictly human. Key words: comparison, origin, feces, streptococci, coliforms. 


\section{Introduction}

Soybean (Glycine max [L.] Merr.) Is a legume cultivated for its seeds which are particularly rich in food proteins (Kouamé et al., 2007) offering many advantages whether on the plant, agronomic, nutritional and economic. It is used in human and animal food. Very rich in nutrients, soy is taken as a food of choice. Due to its nutritional qualities, soy can completely replace meat or fish (Hubert, 2006). In addition, flour made from soybeans is a very recognized enrichment. It can easily be incorporated into other food flours to enrich them with nutrients and thus strengthen cereals and other flour products (Hubert, 2006). Flours can be contaminated with pathogens during the processing of soybeans (FAO / WHO, 2006).

Also the hygiene practices from harvest through processing and marketing observed could promote an increase in the number of emerging pathogens. On the other hand, flour formulas for infants have been consumed by millions of infants for many years. They represent the vast majority of breast milk substitutes commonly used in the world in general and in Côte d'Ivoire in particular.

These preparations consist of special foods, milk substitutes and cereal-based preparations such as soy flour (Codex Alimentarius Commission, 2013). PPNs that meet current microbiological standards are not sterile products.

They can occasionally be contaminated with pathogens (FAO / WHO, 2006) such as emerging opportunistic pathogenic Enterobacteriaceae. (FAO / WHO, 2006). A correlation between infections caused by certain microorganisms and their presence in PNPs has been clearly established. Bacteria of the genus Cronobacter spp. have been implicated in several severe neonatal epidemics such as meningitis, sepsis and gastroenteritis in children (FAO / WHO, 2007). The objective of this study is to compare the physicochemical and microbiological parameters of soybean meal, but also to determine the origin of faecal contamination.

\section{Materials and Methods}

\section{Sampling}

Around sixty (60) samples of soybean flour composed of flour sold in PMI (children's health center) (F1), grains bought at the market and transformed into flour under aseptic conditions in the laboratory (F2) and flour from industrial units sold in supermarkets (F3) in Daloa.

All these samples were transported in a cooler containing carboglaces to the laboratory for microbiological and physicochemical analyzes.

\section{Microbiological analysis technique}

The various microbiological analyzes were carried out taking into account the following standards. These are the NF EN ISO 6887-1, 2017 standards which were used for the preparation of the initial suspension and the decimal dilutions, ISO 21527-1, 2008 for the enumerations of yeasts and molds at $25^{\circ} \mathrm{C} / 7$ days, NF V08-060 and NF ISO 4832, 2006 at $30{ }^{\circ} \mathrm{C} / 24 \mathrm{H}$ for fecal coliforms, NF V 08051,1999 at $30{ }^{\circ} \mathrm{C} / 72 \mathrm{H}$ for aerobic mesophilic bacteria, ISO 4832, 2006 at $45^{\circ} \mathrm{C}$ / 24 hours for the detection and enumeration of E. coli, NF ISO 16649-2, 2001 at $37^{\circ} \mathrm{C} /$ 24 to 48 hours for the detection and enumeration of Staphylococcus aureus, ISO 7932, 2004 at $30^{\circ} \mathrm{C} / 24 \mathrm{H}$ for the detection and enumeration of Bacillus cereus and NF / ISO 16310: 2011 at $44^{\circ} \mathrm{C} / 8 \mathrm{~h}$ for faecal streptococci. 


\section{Expression of microbiological results}

For the calculation of the average microbial loads after enumeration, the following mathematical formula was used.

$N=\frac{\Sigma C i}{\left(N_{1}+0,1 N_{2}\right) d . V}$

$\mathrm{N}$ : number of colony in $\mathrm{CFU} / \mathrm{ml}$;

$\Sigma \mathrm{Ci}$ : sum of the characteristic colonies counted on all the dishes selected;

N1: number of dishes retained at the first dilution;

N2: number of dishes retained at the second dilution;

d: dilution rate corresponding to the first dilution;

$\mathrm{V}$ : volume of the inoculum collected.

\section{Determination of physicochemical parameters}

The determination of physicochemical parameters such as dry matter, ash, $\mathrm{pH}$, moisture content and titratable acidity assay were performed by the method proposed by AOAC, (1995)

\section{Determination of the origin of faecal} contamination

It is based on the criteria defined by Borrego and Romero (1982).By taking into account the fecal coliform / faecal streptococci ratio, the origins of product contamination can be determined (Table 1).

\section{Statistical analyzes}

Analysis of variance (ANOVA I) and Tukey's test were the statistical tools used for data analysis. This analysis was performed using STATISTICA 7.1 software (Statsoft, France).In the event of significant differences between the parameters studied, the classification of the means was made according to the Newmann-Keuls test. The significance level is 0.05.Statistical differences with a probability value less than $0.05(\mathrm{P}<0.05)$ are considered significant. When the probability is greater than $0.05(\mathrm{P}>$ $0.05)$ the statistical differences are not significant. If there was a significant difference $(p<0.05)$ between the means, Tukey's test was performed to determine the different classes of homogeneity.

\section{Results and Discussion}

Comparative study of the physico-physical parameters of the different types of flour

Analysis of the table shows that there is no statistically significant difference between the different types of flour at $\mathrm{P}>0.05$ at the 5\% level for the different parameters (Table 2).

Comparative study of the microbiological parameters analyzed

Analysis of the results shows that there is no statistically significant difference between the different types of flour at $\mathrm{P}>0.05$ at the 5\% level for fecal coliforms and yeasts and molds. Statistical differences with a probability value less than $0.05 \quad(\mathrm{P}<0.05)$ are considered significant so there is a significant difference between F 2 flour and the other two types namely $\mathrm{F} 1$ flour and flourF3 at the level of Mesophilic Aerobic Germs, E. coli and Staphylococcus aureus. There is also a significant difference between the flour F3 and the two other types of flour namely the flour $\mathrm{F}$ 1 and the flour F2 at the level of Bacillus cereus. Furthermore, a significant difference is also noted between F1 flour and the two other types of flour, namely F2 flour and F3 flour in faecal streptococci (Table 3). 


\section{Origin of faecal germs}

The ratios of the mean microbial loads of fecal coliforms and fecal streptococci (CF / SF) of the different types of soybean meal studied were $0.81 ; 4.12$ and 4.15 respectively for the flours F1, F2 and F3.These reports would indicate that these faecal flora are all of various origins. In addition, we note that for F1 flour that $0.7<\mathrm{R}<1$ hence the source of contamination is of mixed predominantly human origin, while the F2 and F3 flours, R> 4 hence the source of contamination is strictly human (Table 4).

The physico-chemical characteristics of the three types of flour analyzed are variable. In addition, the $\mathrm{pH}$ of his samples are acidic and vary from 6.15 to 6.33 . The measured titratable acidity content varies from 0.63 to $0.85 \mathrm{meq} / 100 \mathrm{~g}$. The probabilities of the titratable acidity $(\mathrm{p}=0.08>0.05)$ and of the $\mathrm{pH}(\mathrm{p}=0.31>0.05)$ determined, show that the three types of flour analyzed are not significantly different. This is explained by the fact that the soybeans processed into flour contain the same acidic compounds therefore the different manufactures did not have an impact on the acidity of these. This result is consistent with that of Soro et al., (2013), who asserts that flours that have an acidic $\mathrm{pH}$ are better preserved against attack by microorganisms so these flours could be stored for a long time without risk of microbial spoilage. The dry matter content determined in this study varies from 94.21 to 96.78. This high content indicates a low humidity rate between $3.06 \pm 0.71$ and $5.93 \pm$ 0.50 these humidity levels comply with the standard because dehydrated products must contain less than 15\% humidity (Houphouët, 2016). Furthermore, there is no significant difference between the three types of flour analyzed. However, this low humidity is due to the heat accumulated in the grains. Indeed the grains have been previously roasted and spread, the heat will reduce the amount of water and the low humidity. Thus, these results could promote good conservation of flour for a long time without there being any risk of proliferation and microbial multiplication (WHO / FAO, 2007). According to Akubor, (2005), the determination of the water content is important, since it conditions the implementation of technological tests, such as bread making. Moisture levels are slightly elevated in F1 and F2 flours. These high humidity levels had already been notified in other works could be due to the fact that most millers use second-hand equipment whose performance is seriously reduced, which has the consequence of passing the product several times through grind in the mill if it is not properly hydrated. Probably the use of the right equipment would explain the low humidity levels in this study.

The hydrogen potentials $(\mathrm{pH})$ of the different types of soy flour analyzed are acidic and vary between 5.62 and 6.11 for F3 flour; 6.24 and 6.57 for F 2; 6.18 and 6.32 for F 2 flour. These three types of flour are not significantly different in terms of $\mathrm{pH}$. Moreover, these results are similar to those of cereal flours in other studies carried out by Wakil and Onilude (2009). It appears that the $\mathrm{pH}$ of flour can drop after one month of storage. This could be explained on the one hand by the continuity of the amylase activity of the amylase residues still active in the different types of flour, and on the other hand by the oxidation of fatty acids or be attributable to microbial enzymatic activities. (Saubade et al., 2018). Moreover, according to previous work carried out by Soro et al., (2013), flours which have an acidic $\mathrm{pH}$ are better preserved against attacks from certain undesirable microorganisms.

The observation of an increase in the ash content in the different types of flour is similar to the previous work reported by Leonel et al., 
(2005) for the ash content of Pachyrhizusahipa and those on cassava reported by Chotineeranat et al., (2006). In addition, the ash content is the official means used to characterize the purity of flour (Ballogou et al., 2018). According to GODON and Willm (1991), the determination of the ash offers the possibility of knowing the overall mineral content of the flours. The average microbial loads vary from one type of flour to another and from one parameter to another as well. Thus at the level of mesophilic aerobic germs, a significant difference is noted between the loads of the F2 and F3 flours and that of the F1 flour.

The average microbial load of F1 flour is low and this may be explained by its low moisture content. In fact, the soya beans have been roasted beforehand before transformation into flour. This would also explain the low load in aerobic mesophilic germs, but also in yeasts and molds. Moreover, in a recent study Tarhouni et al., (2015) also showed that roasting grains before their transformation into flour considerably reduced the proliferation of certain germs. Concerning the fecal flora, there is no significant difference in the average microbial loads between the different types of flour at the level of fecal coliforms, on the other hand there is a significant difference between the F2 and F3 flours and that of the F1 flour which is less loaded. in germs at the level of faecal streptococci. However, the presence of germs of fecal origin in all types of flour could be explained by the non-compliance with good hygiene practices during the manufacture of these flours.

Table.1 Criteria for determining the origin of faecal contamination

\begin{tabular}{|c|c|}
\hline Faecal coliforms / faecal streptococci ratio $(\mathbf{R})$ & Source of contamination \\
\hline $\mathbf{R}<\mathbf{0 , 7}$ & Strictly of animal origin \\
\hline $\mathbf{0 , 7}<\mathbf{R}<\mathbf{1}$ & Mixed predominantly animal \\
\hline $\mathbf{1}<\mathbf{R}<\mathbf{2}$ & Uncertain origin \\
\hline $\mathbf{2}<\mathbf{R}<\mathbf{4}$ & Mixed predominantly human \\
\hline $\mathbf{R}>\mathbf{4}$ & Strictly of human origin \\
\hline
\end{tabular}

Table.2 Comparative study of the different types of flour according to the physicochemical parameters

\begin{tabular}{|c|c|c|c|c|c|c|}
\hline & \multicolumn{5}{|c|}{ Values of physicochemical parameters } \\
\hline $\begin{array}{c}\text { Types of } \\
\text { flour }\end{array}$ & $\begin{array}{c}\text { Titratable } \\
\text { acidity }\end{array}$ & $\mathbf{p H}$ & $\begin{array}{c}\text { Moisture rate } \\
\text { (g/100 g MF) }\end{array}$ & $\begin{array}{c}\text { Dry } \\
\text { matter(g/100 g } \\
\text { DM) }\end{array}$ & $\begin{array}{c}\text { Ash(g/100 g } \\
\text { DM) }\end{array}$ & Sugar levels \\
\hline F 1 & $0,73 \pm 0,13^{\mathrm{a}}$ & $6,33 \pm 0,09^{\mathrm{b}}$ & $5,48 \pm 3,27^{\mathrm{c}}$ & $94,53 \pm 3,29^{\mathrm{d}}$ & $5,39 \pm 0,79^{\mathrm{e}}$ & $8,89 \pm 2,20^{\mathrm{f}}$ \\
\hline F 2 & $0,85 \pm 0,21^{\mathrm{a}}$ & $6,15 \pm 0,32^{\mathrm{b}}$ & $5,93 \pm 0,50^{\mathrm{c}}$ & $94,21 \pm 0,55^{\mathrm{d}}$ & $3,93 \pm 1,58^{\mathrm{e}}$ & $8,67 \pm 3,88^{\mathrm{f}}$ \\
\hline F 3 & $0,63 \pm 0,01^{\mathrm{a}}$ & $6,33 \pm 0,14^{\mathrm{b}}$ & $3,06 \pm 0,71^{\mathrm{c}}$ & $96,78 \pm 0,90^{\mathrm{d}}$ & $5,12 \pm 1,26^{\mathrm{e}}$ & $6,84 \pm 0,26^{\mathrm{f}}$ \\
\hline
\end{tabular}

All the means followed by the same letter in superscript on the same column are not significantly different at the probability threshold $\mathrm{P}<0.05 . \mathrm{DM}=$ dry matter $\mathrm{MF}=$ fresh matter F1: Flour purchased from the PMI (health center), F2: Flour obtained from grains purchased in public markets, F3: Flour sold in supermarkets 
Table.3 Comparative study of the average microbial loads of the different types of flour

\begin{tabular}{|c|c|c|c|c|c|c|c|}
\hline $\begin{array}{c}\text { Types de } \\
\text { farines }\end{array}$ & $\begin{array}{c}\text { Germes Aérobies } \\
\text { Mésophiles }\end{array}$ & $\begin{array}{c}\text { Coliforms } \\
\text { fécaux }\end{array}$ & $\begin{array}{c}\text { Levures et } \\
\text { Moisissures }\end{array}$ & $\begin{array}{c}\text { Escherichia } \\
\text { coli }\end{array}$ & $\begin{array}{c}\text { Staphylococcus } \\
\text { aureus }\end{array}$ & $\begin{array}{c}\text { Streptocoques } \\
\text { fécaux }\end{array}$ & $\begin{array}{c}\text { Bacillus } \\
\text { cereus }\end{array}$ \\
\hline F1 & $10^{5} \pm 60^{\mathrm{b}}$ & $9,6.10^{2} \pm 35^{\mathrm{a}}$ & $332 \pm 37^{\mathrm{a}}$ & $9,5.10^{2} \pm 14^{\mathrm{b}}$ & $8,410^{3} \pm 11^{\mathrm{b}}$ & $11,5.10^{3} \pm 147^{\mathrm{b}}$ & $3,9.10^{2} \pm 88^{\mathrm{a}}$ \\
\hline F2 & $1,4.10^{2} \pm 21^{\mathrm{a}}$ & $6,6.10^{2} \pm 87^{\mathrm{a}}$ & $554 \pm 61^{\mathrm{a}}$ & $0 \pm 0^{\mathrm{a}}$ & $0 \pm 0^{\mathrm{a}}$ & $1,6.10^{3} \pm 115^{\mathrm{a}}$ & $5,0.10^{2} \pm 108^{\mathrm{a}}$ \\
\hline F3 & $6,1.10^{2} \pm 11^{\mathrm{a}}$ & $5,4.10^{2} \pm 32^{\mathrm{a}}$ & $454 \pm 55^{\mathrm{a}}$ & $3,6.10^{4} \pm 13^{\mathrm{b}}$ & $2.10^{4} \pm 20^{\mathrm{b}}$ & $1,3.10^{3} \pm 96^{\mathrm{a}}$ & $3,5.10^{3} \pm 197^{\mathrm{b}}$ \\
\hline
\end{tabular}

All the means followed by the same letter in superscript on the same column are not significantly different at the probability threshold $\mathrm{P}<0.05$.DM $=$ dry matter MF = fresh matter, F1: Flour purchased from the PMI (health center), F2: Flour obtained from grains purchased in public markets, F3: Flour sold in

supermarkets

Table.4 Faecal coliforms / faecal streptococci ratio of the different types of soybean meal studied

\begin{tabular}{|c|c|c|}
\hline $\begin{array}{c}\text { Faecal coliforms / faecal } \\
\text { streptococci ratio (R) }\end{array}$ & Values found & Source of contamination \\
\hline F1 & 0,81 & Mixed origin predominantly human \\
\hline F2 & 4,12 & Strictly of human origin \\
\hline F3 & 4,15 & Strictly of human origin \\
\hline
\end{tabular}

F1: Flour purchased from the PMI (health center), F2: Flour obtained from grains purchased in public markets, F3: Flour sold in supermarkets 
With regard to potentially pathogenic germs, namely E. coli and Staphylococcus aureus, a significant difference is noted between the F2 flour and the other two flour, namely F1 and F3. Indeed we find a high microbial load in F1 and F2 flour. In recent studies, similar results have been found by Malete et al., (2013), Sanou et al., (2017) in infant flours produced in an artisanal way. Moreover, the presence of these germs reflects a health risk for the consumer. According to the work carried out by Mesa et al., (2006) some strains of E. coli are pathogens causing diarrhea which can be fatal in warm-blooded humans and animals. These strains are usually found in environments where sanitary conditions are poor. Furthermore, the presence of potentially pathogenic germs such as Bacillus cereus, E. coli and Staphylococcus aureus is justified by the ubiquitous nature of the latter. These bacteria, which are very widespread in the environment and moreover saprophytic in humans and warm-blooded animals, are found in flour during processing. Also, the process for transforming these flours remains traditional. Thus, the production time is long and the inadequate hygienic conditions could constitute routes of contamination of these products. In addition, some authors such as Adjilea et al., (2015) revealed in a recent study on the characterization of the traditional technology of production of flour from corn, that the milling would be a critical step, dependent on the sunshine and the level of healthiness of the immediate environment.

The comparative study carried out on the physicochemical and microbiological parameters revealed some significant differences on certain physical and microbiological parameters. The presence of potentially pathogenic germs in certain types of flour can cause serious illness, including death of infants. Therefore, the consumption of soy flour sold in markets, supermarkets and PMI would present risks for children and especially for infants. There are various sources of contamination of flour by faecal germs.

\section{References}

Adjilea N., Houssou A. P. F., Monteiro N., Fainou M. C., Akissoe N. H. and Toukourou F., (2015). Caractérisation du procédé de gambari-lifin (farine de maïs décortiqué dégermé) et influence de la variété de maïs sur la qualité physicochimique et rhéologique. Nature \& Technologie. B- Sciences Agronomiques et Biologiques, $\mathrm{n}^{\circ} 12$

Akubor, P. I. 2005. Effects of defatting on chemical, functional and storage properties of melon (Colocynthiscitrullus) seed flour. Journal of Food Science and Technology, 42 : 472-474.

AOAC. Official methods of analysis, V.A: Association of Official Analytical Chemists, Arlington, Washington D.C, 1995.

Ballogou,V. Y., Djidohokpin, M. E., Manful, J. T. and Soumanou, M. M. (2018). "Formulation d'aliments de complément à partir du soja et de deux écotypes de fonio," Nature \&Technology, (10)2 : 18-24,

Borrego A. F and Romero P. (1982). Study of microbiological pollution of malaga littoral area II, Relation ship between fecal colifors and fecal streptococci, VIèmejournéeétudes. Pollution Cannes, 561-569

CAC (Commission du Codex Alimentarius), Lignes directrices pour la mise au point des préparations alimentaires complémentaires destinées aux nourrissons du deuxième âge et aux enfants en bas âge (CAC/GL 08-1991), 2013. [Online] Available: www.fao.org/input/download/standard s/298/CXG_008f.pdf (June 22 2019). 
FAO/OMS (2006), Programme mixte FAO/OMS sur les normes alimentaires. Rapport des vingt septième sessions du comité du codex sur la nutrition et les aliments diététiques ou de régime, ALINOM 06/29/26, pp. 1-105,.

FAO/OMS (2007). Céréales, légumineuses dans l'alimentation humaine. Alimentation et

nutrition, $20: 1-152 \mathrm{p}$.

Godon B and Willm C. 1991. Les industries de première transformation des céréales. Techniques et documentation. Tec \& Doc, Éditions Lavoisier, Paris, $679 \mathrm{p}$.

Houphouët K. R. 2016. Caractérisation physicochimique et qualité sanitaire des farines infantiles vendues dans les centres de santé d'Abidjan, Mémoire pour l'obtention de stage de Master de Microbiologie et biologie moléculaire, UFR des Sciences et Technologies des Aliments, Université Nagui Abrogoua, Abidjan, Côte d'Ivoire, $69 \mathrm{p}$.

Hubert J. (2006). Caractérisation biochimique et propriétés biologiques des micronutriments

du germe de soja, Etude des voies de sa valorisation en nutrition et santé humaines. Thèse de doctorat, École doctorale des Sciences Ecologiques, Vétérinaires, Agronomiques et Bioingénieries, Qualité et sécurité des aliments, Toulouse. Consulté le Décembre 18, 2012.

Kouamé, C., N'gbesso, M., Adako, $\mathrm{M}$ and Tahouo.O. 2007. Bien cultive le soja en Côte d'Ivoire. p4.

Leonel, M., Ferrari, T. B., Sarmento, S. B. S. Oliveira and M. A. 2005. Planting time, developmental stages and characteristics of roots and starch of Pachyrhizusahipa. Scientia Agricola (Piracicaba, Braz.), (62) 6 :528-533

Malete Y., Sessou P., Farougou S., Metohoue
R. and So- hounhloue, D. 2013. Évaluation de la qualité hygié- nique de Tchaamessibu, une pâte acide consommée à Natitingou au nord Bénin. Revue de Microbiologie Industrielle Santé et Environnement7: 228-244

Mesa, R. J., Blanc, V., Blanch, A. R., Cortes, P., Gonzalez, J. J., Lavilla, S., Miro, E., Muniesa, M., Saco, M., Tortola,, M. T., Mirelis B., Coll, P., Llagostera, M., Prats, G and Navarro, F.2006. Extended- spectrumbeta- lactamaseproducing Enterobacteriaceae in different environments (humans, food, animal farms and sewage). Journal of AntimicrobChemother,58:211- 5.

NF EN ISO 6887-1, 2017. Microbiologie des aliments - Préparation des échantillons, de la suspension mère et des dilutions décimales en vue de l'examen microbiologique - Partie 1: règles générales pour la préparation de la suspension mère et des dilutions décimales, 20p.

NF ISO 16649-2, 2001. Microbiologie des aliments - Méthode horizontale pour le dénombrement des Escherichia coli $\beta$ glucuronidase positive. Partie 2: Technique de comptage des colonies à $44^{\circ} \mathrm{C}$ au moyen d'acide 5-bromo-4chloro-3-indolyl- $\beta$-D-glucuronate, $55 \mathrm{p}$.

NF EN ISO 6888-1, 2004. Microbiologie des aliments. Méthode horizontale pour le dénombrement des staphylocoques à coagulase positive (Staphylococcus aureus et autres espèces). Partie 1 : Technique utilisant le milieu gélosé de Baird-Parker, 45p.

NF EN ISO 21527-2, 2008. Microbiologie des aliments - Méthode horizontale pour le dénombrement des levures et moisissures - Partie 1: Technique par comptage des colonies dans les produits alimentaires 9 pages

NF EN ISO 7932, 2004.Microbiologie des 
aliments, méthode horizontale pour le dénombrement de Bacillus cereus présomptifs, comptage des colonies à $30^{\circ} \mathrm{C}, 12$ pages

NF V08-051, 1999.Microbiologie des aliments Dénombrement des microorganismes par comptage des colonies obtenues à $30^{\circ} \mathrm{C}$. Méthode de routine. $8 \mathrm{p}$.

Sanou A., Tapsoba F., ZongoC.,Savadogo A and Traore Y. 2017. Étude de la qualité nutritionnelle et microbiologique des farines infantiles de quatre unités de production : CMA saint Camille de Nanoro, CSPS Saint Louis de Temnaore, CM saint Camille d'Ouagadougou et CHR de Koudougou, Nature \&Technology Journal. Vol. B :Agronomic \& Biological Sciences, 17: 25-39.

Saubade, F., Hemery, Y. M., Rochette, I., Guyot, J.-P and Humblot, C. 2018. Influence of Fermentation and Other Processing Steps on the Folate Content of a Traditional African Cereal-Based
Fermented Food. International Journal of Food Microbiology,266 : 79-86

Soro, S., Konan, G., Elleingand,E., N'guessan, D and Koffi, E. (2013) "Formulation d'aliments infantiles à base de farines d'igname enrichies au soja," African Journal of Food Agriculture, Nutrition and Development, (13) $5: 8339-8316$.

Tarhouni, A., Djendoubi, N., Amri F., Elbour, M., Sadok, S andMihoubi, B.N. 2015. Mise au point d'un procédé intégré de valorisation de la sardinelle: effet de la température et du blanchiment sur la valeur nutritionnelle et de la qualité microbiologique des produits finis. Bulletin de l'Institut National des Sciences et Technologies de la Mer Salammbô, 42: 69-71.

Wakil, S. M. and Onilude, A. 2009. Microbiological and chemical changes during production of malted and fermented Cereal-Legume weaning foods. Advances in food sciences, 31: $139-145$.

\section{How to cite this article:}

Kouassi Kra Athanase, Gnanwa Mankambou Jacques, Kouassi Kouassi Clément, Coulibaly Bakary and Coulibaly Ibourahema. 2021. Comparative Study of Some Physico-Chemical, Microbiological Parameters and Origins of Faecal Contamination of Three Types of Soybean Flour Sold in the City of Daloa (Côte d'Ivoire). Int.J.Curr.Microbiol.App.Sci. 10(07): 778-786. doi: https://doi.org/10.20546/ijcmas.2021.1007.085 